\title{
Fast Axonally Transported Proteins in Regenerating Goldfish Optic Axons
}

\author{
G. W. Perry, ${ }^{a}$ Donald W. Burmeister, ${ }^{b}$ and Bernice Grafstein \\ Department of Physiology, Cornell University Medical College, New York, New York 10021
}

Fast axonal transport of protein was examined in regenerating goldfish optic axons after a lesion of either the optic tract or optic nerve, which revealed changes in the original intact optic axon segments or in the newly regenerated axon segments, respectively.

In animals killed either 6 or $24 \mathrm{hr}$ after injection of ${ }^{3} \mathrm{H}$ proline into the eye, labeling of total fast-transported protein in the original axon segments was increased by $2 \mathrm{~d}$ after the lesion, reached a peak of nearly $20 \times$ normal at 2 weeks, and then declined to a level somewhat above normal at 12 weeks. When the labeling of individual transported proteins was examined by 2-dimensional gel electrophoresis, it was found that no new labeled proteins appeared during regeneration, but all proteins examined showed an increase in labeling. Among the various proteins, there was great variation in the magnitude and time course of the labeling increase. The largest increase, to nearly $200 \times$ normal with 6 hr labeling, was seen in a protein with a molecular weight of $45 \mathrm{kDa}$ and a p/ of about 4.5 , resembling a protein that has previously been designated a "growth-associated protein" (GAP-43; Skene and Willard, 1981a). The proteins showing increased labeling included a small fraction of cytoskeletal proteins ( $\alpha$-tubulin, $\beta$-tubulin, and actin) that was apparently transported at a much faster rate than is usually expected of these constituents.

In the new axon segments, the total protein labeling was increased by 1 week after the lesion, remained elevated at a nearly constant level of about $7 \times$ normal from about 2 to 5 weeks, and then declined to levels somewhat above normal by 12 weeks. The $45 \mathrm{kDa}$ protein again showed the largest increase, and became the single most prominently labeled constituent in the new axons.

On the basis of the time course of labeling in both original and new axon segments during regeneration, the fast-transported proteins were tentatively separated into 5 classes that may represent groups of proteins that are coregulated during regeneration. They may conceivably correspond to different functional or structural entities within the neuron.

Received Apr. 7, 1986; revised July 26, 1986; accepted Sept. 25, 1986.

This work was supported by NIH Grants NS-09015 and NS-14967 and by Training Grant NS-07138.

Correspondence should be addressed to Dr. Grafstein at the above address.

a Present address: Department of Physiology and Biophysics, University of Miami School of Medicine, Miami, FL 33101.

b Present address: Department of Pharmacology, Columbia University College of Physicians and Surgeons, New York, NY 10032.

Copyright (c) 1987 Society for Neuroscience $0270-6474 / 87 / 030792-15 \$ 02.00 / 0$
In some nerve cells axonal regeneration is accompanied by a massive increase in the synthesis and axonal transport of proteins (reviewed by Forman, 1983). Even nerve cells that do not show an overall increase in protein transport may show increased transport of a limited number of constituents (Perry and Wilson, 1981). The significance of the increased transport and the role that the transported materials may play in regeneration are important issues for the understanding of the regenerative process.

Axonal regeneration in the retinal ganglion cells of the goldfish involves a dramatic increase in the synthesis of axonally transported proteins, as indicated by the increased incorporation of radioactively labeled amino acids (Murray and Grafstein, 1969; Giulian et al., 1980; Benowitz et al., 1981; Heacock and Agranoff, 1982). Labeling of proteins in fast axonal transport begins to increase by 1-2 d after a lesion of the optic axons and reaches a maximum at 2-3 weeks (Grafstein and Alpert, 1976; McQuarrie and Grafstein, 1982a). These changes appear to affect a large number of fast-transported proteins (Benowitz et al., 1981). A large and early increase has been observed in an acidic protein with a molecular weight of about $45 \mathrm{kDa}$ (Benowitz et al., 1981; Heacock and Agranoff, 1982; Benowitz and Lewis, 1983; Perry et al., 1985), which resembles one of the "growthassociated proteins" (GAP-43) that show a dramatic increase in labeling in other regenerating nerves (Skene and Willard, $1981 \mathrm{a}, \mathrm{b})$. There is also an increase in labeling of proteins in slow axonal transport (McQuarrie and Grafstein, 1982b), including tubulin (Heacock and Agranoff, 1982).

In the present study we have examined the regeneration-associated changes of fast axonal transport in goldfish retinal ganglion cells in a systematic way, by means of a quantitative analysis of the changes in incorporation of ${ }^{3} \mathrm{H}$-proline into a broad array of fast-transported proteins as observed throughout the course of regeneration. Subsequent papers will deal with corresponding changes in slow transport and with the effects of removing the target lobe of the optic tectum.

Preliminary accounts of some of this work have appeared previously (Burmeister et al., 1983; Grafstein et al., 1987).

\section{Materials and Methods}

Animals. Goldfish (Carassius auratus) $9-11 \mathrm{~cm}$ in body length and 30$40 \mathrm{gm}$ in weight were obtained from Ozark Fisheries, Stoutland, MO. They were maintained in 10 gallon aquaria at room temperature (approximately $21^{\circ} \mathrm{C}$ ) with a $14 / 10 \mathrm{hr}$ on-off light cycle.

Surgical procedures. Goldfish were anesthetized with ice. In one group of fish, a skull flap was made and the left optic tract (projecting from the right eye) was transected intracranially, close to where it enters the left lobe of the optic tectum. In another group of fish, the right optic nerve was crushed for $3 \mathrm{sec}$ at a point in the orbit $2 \mathrm{~mm}$ behind the eye. A third group of fish, in which only a skull flap was made and put 

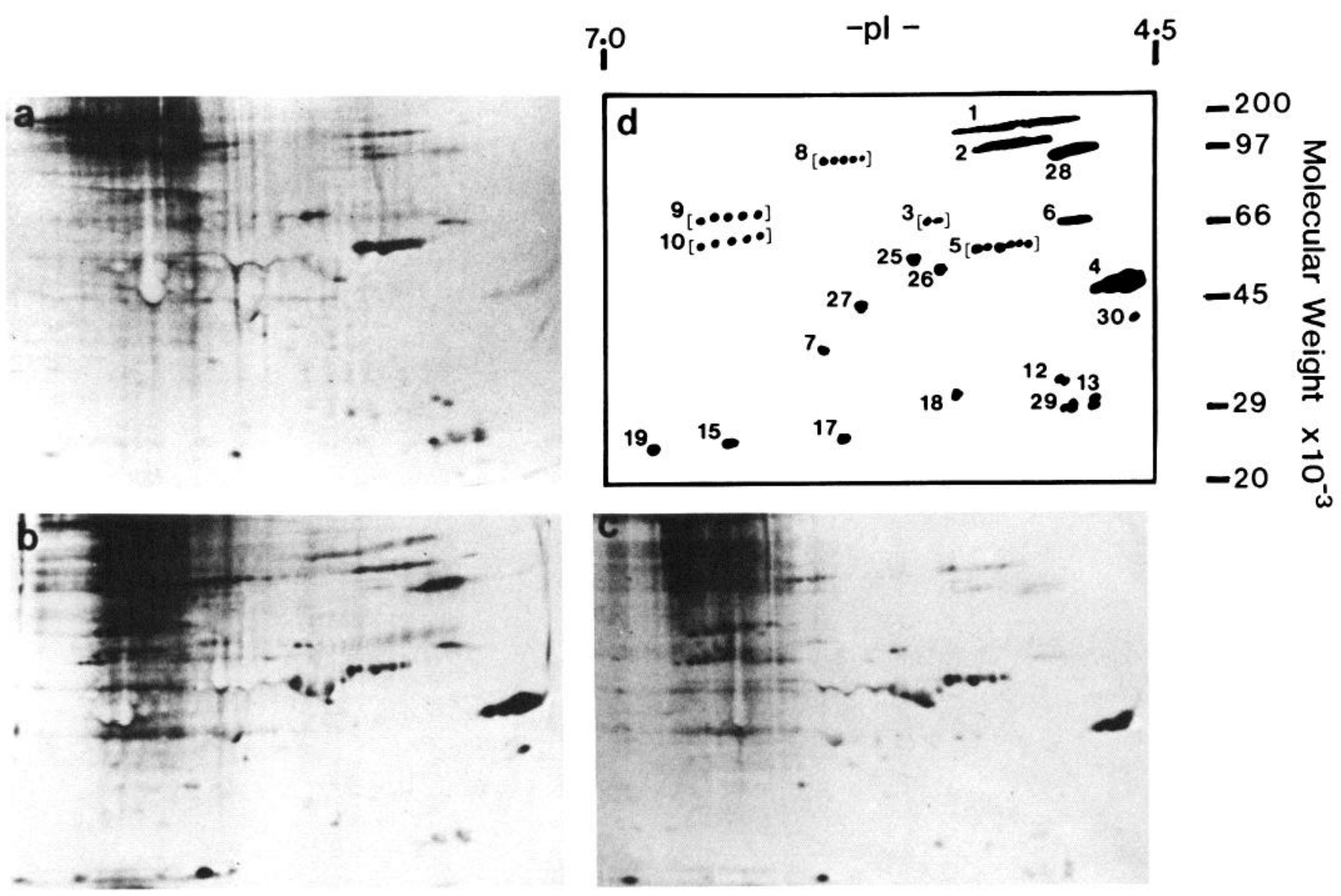

Figure 1. Fluorographic patterns of transported proteins separated on 2-dimensional polyacrylamide gels following $6 \mathrm{hr}$ intraocular labeling from $(a)$ control (sham-operated) nerves; $(b)$ nerves from fish that had undergone an optic-tract lesion 2 weeks earlier; $(c)$ nerves from fish that had undergone a tract lesion 12 weeks earlier. Exposure times of fluorographs: $(a) 3$ months; $(b) 3$ weeks; (c) 10 weeks. (Apparent changes in spot intensity may reflect different exposures rather than actual dpm in the spot, as with no. 13.) $d$, Map showing rapidly transported proteins that were consistently seen in these experiments and on which quantitative determinations were made. Molecular-weight standards (Sigma) were 20,000 (myoglobin), ¿29,000 (carbonic anhydrase), 45,000 (ovalbumin), 66,000 (bovine serum albumin), 97,000 (phosphorylase B), and 200,000 (myosin). The more neutral region of the gel (left side) often showed some nonspecific reduction of the $\mathrm{x}$-ray film, but individual spots in this region were usually clearer in the original fluorographs than in the photographs shown. The origin of this nonspecific labeling is not known. It may result from the presence of poorly focusing high-molecular-weight proteins (possibly proteoglycans) in the less acidic part of the gel (cf. Benowitz and Lewis, 1983).

back in place, served as sham-operated controls from which normal nerve values were obtained.

Radiolabeling, transport, and tissue sample preparation. At various times after surgery, the goldfish received an intraocular injection of 30 $40 \mu \mathrm{Ci}{ }^{3} \mathrm{H}$-proline (New England Nuclear; $100 \mathrm{Ci} / \mathrm{mmol}$ ) into the vitreous of the right eye. At 6 or $24 \mathrm{hr}$ following intraocular injection, the goldfish were killed by decapitation and the right optic nerve removed, together with its optic tract. A $2 \mathrm{~mm}$ segment of nerve adjacent to the back of the eye and a $2 \mathrm{~mm}$ segment adjacent to the original tract cut were discarded in order to eliminate radioactively labeled material that may have leaked out of the eye or accumulated at the site of the lesion, respectively. The remaining nerve sample was usually $6 \mathrm{~mm}$ in length. Two or more such samples were homogenized together in a small glass grinder containing $30 \mu \mathrm{l}$ of the homogenization solution described by Perry et al. (1985). The tissue grinder was rinsed with a further $30 \mu \mathrm{l}$, which was added to the homogenate. The homogenate was then centrifuged at $100,000 \times g$ for $30 \mathrm{~min}$ at room temperature. For the measurement of total protein labeling, $5 \mu \mathrm{l}$ of the supernatant was added to $1.0 \mathrm{ml}$ of $5 \%$ (wt/vol) trichloroacetic acid (TCA), allowed to stand for $10 \mathrm{~min}$, and then centrifuged at $7000 \times g$ for $20 \mathrm{~min}$ (Perry and Wilson, 1981). The resulting precipitate was solubilized in $0.33 \mathrm{ml}$ of Soluene S-100 (Packard Instruments) for $1 \mathrm{hr}$ at $50^{\circ} \mathrm{C}$ and counted in a toluene-based scintillation fluid in a Beckman LS-7500 counter with an efficiency for ${ }^{3} \mathrm{H}$ of about $35 \%$. Measurements were expressed in disintegrations per minute (dpm) per $\mu \mathrm{Ci}$ injected per nerve sample. The remaining supernatant was subjected to 2-dimensional PAGE.

Gel electrophoresis. PAGE was performed as described previously (Perry et al., 1983, 1985) according to the general principles of O'Farrell (1975). Separation was between $\mathrm{p} / \mathrm{s}$ of 4.5 and 7.0 in the isofocusing dimension, and of $20,000-200,000 \mathrm{kDa}$ in the molecular-weight dimension on a $10 \%$ gel. We have found that most of the optic nerve proteins detected by 2D-PAGE, including those rapidly transported along axons, lie within the ranges of $\mathrm{p} I$ and molecular weight selected for these gels (E. Antonian and G. W. Perry, unpublished observations).

Fluorography and quantitative analysis of gel patterns. After staining and destaining, the gels were subjected to the fluorographic enhancement procedure of Bonner and Laskey (1974) and Laskey and Mills (1975). The dried gels were used to expose preflashed Kodak XAR $5 \mathrm{x}$-ray film (Laskey and Mills, 1975) at $-80^{\circ} \mathrm{C}$ for several weeks to several months, depending on the amount of radioactive protein loaded onto the gel. Quantitative analysis was performed essentially as described by Perry and Wilson (1981). Since few of the rapidly transported proteins were present in sufficient quantities to be detectable by the Coomassie brilliant blue staining (Perry et al., 1985), the gel areas corresponding to labeled spots on the fluorographs were located by projecting the fluorographic pattern onto the dried gel (Perry and Wilson, 1981) and then cutting the appropriate areas out of the gels. For excision of the spots occupied by $\alpha$-and $\beta$-tubulin and actin, the gel staining pattern was also 

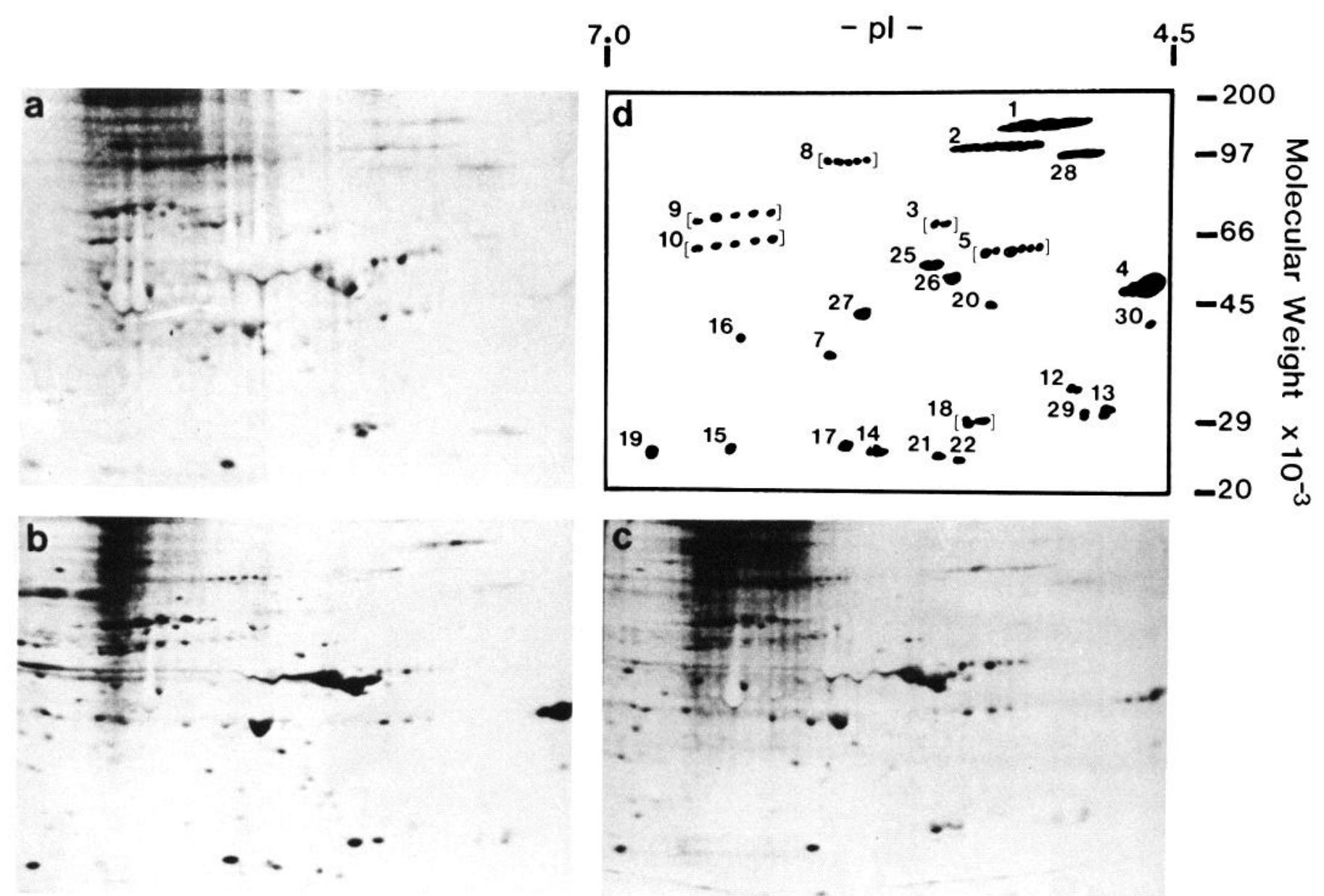

Figure 2. Fluorographic patterns of transported proteins from (a) control, $(b) 2$ week regenerating, and $(c)$ 12-week regenerating nerves, obtained following $24 \mathrm{hr}$ intraocular labeling in tract-lesion experiments (details as in Fig. 1).

a useful guide. Each gel piece was solubilized overnight in a vial containing $1.0 \mathrm{ml}$ of Soluene S100 or S350 (Packard Instruments), after which $4.0 \mathrm{ml}$ of toluene-based scintillation fluid was added and radioactivity determined in a liquid-scintillation counter. Each protein investigated was identified by an arbitrarily assigned number.

To reduce the within-group variation in labeling (e.g., due to differences in the transport, gel-to-gel variability, or individual animal differences), the raw dpm values for each spot were normalized against the mean total dpm recovered in the whole population of spots from all the gels chosen for analysis in a given experimental group as follows:

Normalized dpm for spot

$=\mathrm{dpm}$ for that spot in $1 \mathrm{gel}$ $\times\left(\frac{\text { mean (total dpm of spots) for all gels in group }}{\text { total dpm of spots in the same gel }}\right)$.

Mean normalized values for each experimental point (e.g., Fig. 5, Table 1) were calculated from the normalized $\mathrm{dpm}$ values obtained for each spot from all the gels $(n=3-6)$ in the group. These values indicated ${ }^{3} \mathrm{H}$-proline incorporation for each protein, independent of changes in any of the others. This represented a departure from the approach used in some previous studies, where the changes in various individual proteins were measured relative to the overall changes in the protein population. (Skene and Willard, 1981b; Szaro et al., 1985). (The latter approach emphasizes the proteins that show a large change relative to the others, while minimizing the role of proteins that show a smaller change but make a large contribution to the total labeling.)

\section{Results}

Axonal transport under control conditions

Figures 1 and 2 show representative 2D-gel labeling patterns of transported optic nerve proteins obtained following intraocular labeling with ${ }^{3} \mathrm{H}$-proline for 6 and $24 \mathrm{hr}$, respectively. There were 26 prominent and consistently seen spots that could be attributed to labeling of axonally transported proteins. Some of these proteins appeared as a horizontal band or a series of multiple spots of similar molecular weight but different $\mathrm{p}$ Is (Stone et al., 1978). This appearance is thought to have been due to charged groups on the proteins, for example, sugar residues or sulfate or phosphate groups (Stone et al., 1983). Such a horizontal band or series of spots was therefore considered to be a single protein (e.g., 5).

In control nerves (Figs. $1 a$ and $2 a$ ), a number of the transported proteins showed a significant decrease in labeling between 6 and $24 \mathrm{hr}(1,2,3,5$, and 28), whereas others $(7,10$, $15,16,18$, and 20) showed a significant increase (Table 1). A few proteins $(14,21$, and 22$)$ that appeared only in the fluorographs of 24-hr-labeled nerves, and contained too little radioactivity for measurement by scintillation counting (although their labeling increased greatly during regeneration; see below) should also be included in the second category. The remaining 


\begin{tabular}{|c|c|c|c|}
\hline \multirow{2}{*}{ nerv } & \multicolumn{2}{|c|}{ Mean normalized dpm ${ }^{a}( \pm \mathrm{SEM})$} & \multirow{2}{*}{$\begin{array}{l}\text { Ratio } \\
(6 \mathrm{hr}: 24 \mathrm{hr})\end{array}$} \\
\hline & $6 \mathrm{hr}(n=6)$ & $24 \mathrm{hr}(n=7)$ & \\
\hline 1 & $160 \pm 26^{*}$ & $57 \pm 13$ & 2.8 \\
\hline 2 & $176 \pm 14^{*}$ & $98 \pm 8$ & 1.8 \\
\hline 3 & $67 \pm 22^{*}$ & $20 \pm 3$ & 3.3 \\
\hline 4 & $38 \pm 9$ & $82 \pm 18$ & 0.5 \\
\hline 5 & $370 \pm 43^{*}$ & $136 \pm 15$ & 2.7 \\
\hline 6 & $35 \pm 6$ & $25 \pm 1$ & 1.4 \\
\hline 7 & $14 \pm 4$ & $37 \pm 4^{*}$ & 0.4 \\
\hline 8 & $272 \pm 29$ & $278 \pm 28$ & 1.0 \\
\hline 9 & $382 \pm 48$ & $314 \pm 17$ & 1.2 \\
\hline 10 & $28 \pm 17$ & $161 \pm 17^{*}$ & 0.2 \\
\hline 12 & $10 \pm 2$ & $8 \pm 1$ & 1.2 \\
\hline 13 & $24 \pm 7$ & $22 \pm 3$ & 1.1 \\
\hline 14 & & $-b$ & $<1$ \\
\hline 15 & $6 \pm 1$ & $19 \pm 3^{*}$ & 0.3 \\
\hline 16 & & $42 \pm 10^{*}$ & $<1$ \\
\hline 17 & $32 \pm 7$ & $43 \pm 6$ & 0.7 \\
\hline 18 & $17 \pm 3$ & $81 \pm 10^{*}$ & 0.2 \\
\hline 19 & $18 \pm 1$ & $18 \pm 3$ & 1.0 \\
\hline 20 & & $15 \pm 6^{*}$ & $<1$ \\
\hline 21 & & - & $<1$ \\
\hline 22 & & - & $<1$ \\
\hline 25 & $47 \pm 7$ & $73 \pm 12$ & 0.6 \\
\hline 26 & $44 \pm 5$ & $63 \pm 12$ & 0.7 \\
\hline 27 & $74 \pm 18$ & $124 \pm 18$ & 0.6 \\
\hline 28 & $61 \pm 4^{*}$ & $41 \pm 5$ & 1.5 \\
\hline 29 & $27 \pm 6$ & $20 \pm 3$ & 1.4 \\
\hline 30 & $7 \pm 2$ & $7 \pm 2$ & 1.0 \\
\hline
\end{tabular}

${ }^{a}$ For normalization procedure, see text.

${ }^{b}$ Values that could not be obtaincd because the spots were visible on fluorographs but contained too little radioactivity to be measured by scintillation counting.

${ }^{*} p<0.05$ for difference between $6 \mathrm{hr}$ and $24 \mathrm{hr}$ values.

proteins showed no significant change in labeling between 6 and $24 \mathrm{hr}$.

\section{Axonal transport during regeneration}

Regeneration of the optic axons proceeds as effectively after cutting the optic tract as after crushing the optic nerve (Grafstein, 1986). The axons have to grow a few millimeters further to reach the optic tectum in the case of the nerve lesion, but the time required for reinnervation of the tectum is only a few days longer (Grafstein, 1986). However, measurements of the radioactively labeled proteins conveyed by axonal transport in the optic nerve have different significances, depending on the site of the lesion. If the lesion is in the optic tract, the nerve sample (Fig. 3, top) contains the segments of the original axons that have remained connected to their cell bodies, whereas with the lesion close to the eye, e.g., an optic nerve crush, the optic nerve sample contains the new axon segments (Fig. 3, bottom). Thus it is possible to correlate events in the original ("parent") axon segments and the new axon segments by comparing the results from the tract-lesion and nerve-lesion experiments, respectively.

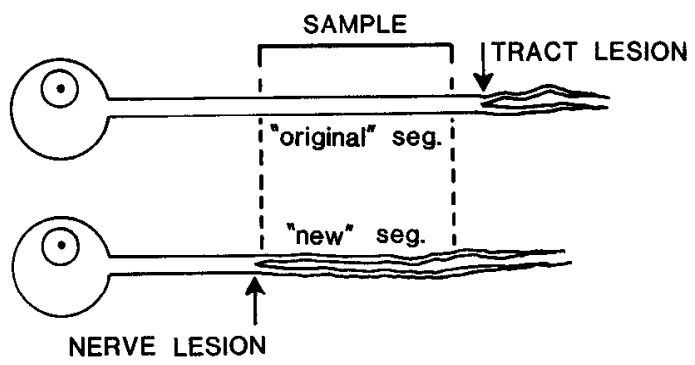

Figure 3. Diagram showing relationship between lesion site and composition of nerve sample in tract-lesion experiments (top) and nervelesion experiments (bottom). The sample contains the original axon segments in the former case, the new axon segments in the latter.

\section{Axonal transport in the original axon segments: total protein labeling}

With a $6 \mathrm{hr}$ labeling interval in optic tract-lesioned animals, a large increase in total protein labeling (Fig. $4 A$ ) occurred during the course of regeneration, as has previously been reported (Grafstein and Murray, 1969; Grafstein and Alpert, 1976; McQuarrie and Grafstein, 1982a). Some increase in labeling was already evident at $2 \mathrm{~d}$, and a peak of nearly $20 \times$ normal was seen at 2 weeks, when the regenerating axons were known to be invading the optic tectum (Grafstein, 1986). By 5 weeks, labeling was sharply reduced from its peak, but it was still significantly higher than normal at 12 weeks. The increased labeling was not accompanied by any significant change in the protein

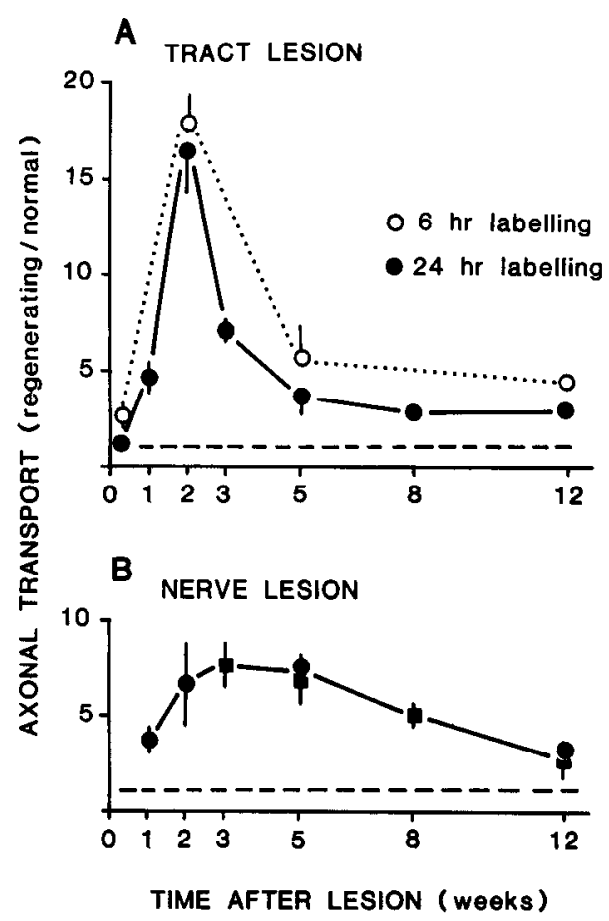

Figure 4. Labeling of total transported protein in optic nerve sample in $(A)$ tract-lesion experiments and $(B)$ nerve-lesion experiments, measured $6 \mathrm{hr}$ (open circles) and $24 \mathrm{hr}$ (filled symbols) after intraocular injection of ${ }^{3} \mathrm{H}$-proline. Measurements of total transported TCA-precipitable radioactivity were expressed in $\mathrm{dpm} / \mu \mathrm{Ci}$ injected per nerve sample, and the values for the regenerating nerves were divided by the mean value for normal nerves (from sham-operated fish), as indicated by the broken line. Each point is the mean \pm SEM of 2-7 samples, containing 1 or 2 nerves. $B$, Two separate series of experiments are indicated by different symbols. 
Figure 5. Quantitative analysis of $6 \mathrm{hr}$ labeling of individual transported proteins separated on 2-dimensional polyacrylamide gels obtained from optic nerves after a lesion of the optic tract. Numbering of spots as in map in Figures 1 and 2. Each point represents the normalized mean \pm SEM of 3-6 determinations (see Materials and Methods for normalization procedure). In some cases, the SEM bar does not extend beyond the limits of the symbol used for the point.



Among the transported proteins that became heavily labeled with ${ }^{3} \mathrm{H}$-proline during regeneration, especially with $24 \mathrm{hr}$ labeling, were the cytoskeletal proteins $\alpha$ - and $\beta$-tubulin and actin (25-27). Tubulin and actin were identified by their comigration with the purified proteins (see Perry et al., 1985).

All the transported proteins that were sufficiently labeled for quantitative determinations increased their incorporation of label during regeneration, although not to the same degree (Figs. 5 and 6). With $6 \mathrm{hr}$ labeling (Fig. 5), a number of proteins already showed a significant increase in labeling by $2 \mathrm{~d}$ after the optic tract lesion (Table 2). Most of the proteins showed an increase of 3-fold or less. The largest change, an increase of nearly 6-fold, was seen in spot no. 4 , which is identical to the $45 \mathrm{kDa}$ protein described by Benowitz et al. (1981; Benowitz and Lewis, 1983). A few proteins, e.g., 6, 9, and 10 , were virtually undetectable in the $2 \mathrm{~d}$ fluorographs, indicating decreased labeling, but the decrease could not be accurately quantified. In a few cases, such as 1,25 , and 26 , a quantitative measure of the decrease could be obtained, although the change was not statistically significant (Table 2). Maximum labeling was seen in almost all the proteins at about 2 weeks after the lesion (Fig. 5) The largest change, a nearly 200 -fold increase, was again seen in 4 , whereas for most of the other proteins the increase was 5- to 30-fold (Table 2). A considerable degree of recovery was evident for most of the 


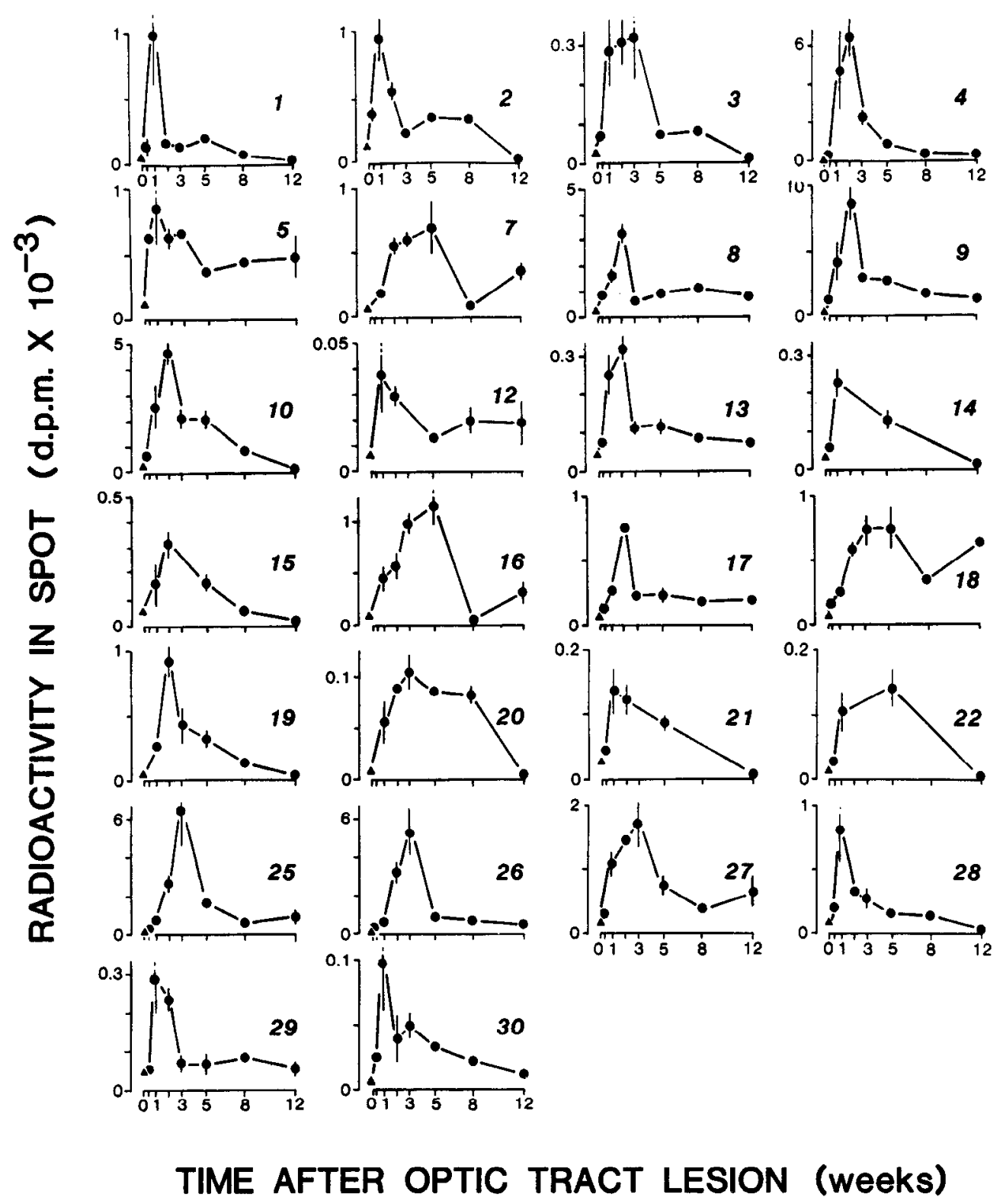

Figure 6. Quantitative analysis of 24 $\mathrm{hr}$ labeling of individual transported proteins following an optic tract lesion (compare Fig. 5). Each point represents the normalized mean \pm SEM of 3-6 determinations. proteins by 5 weeks, and near normal levels were reached by 12 weeks. Minor divergences from this pattern were seen in 12, 15,18 , and 26.

The picture seen with $24 \mathrm{hr}$ labeling was initially similar to that of $6 \mathrm{hr}$ (Fig. 6), with many of the proteins showing a significant increase in labeling by $2 \mathrm{~d}$ after the optic tract lesion (Table 3), although the labeling of spot no. 4 was not significantly elevated at this time. In this experiment, in which a close series of early time points was recorded, it was seen that the maximum change displayed by the different proteins varied greatly not only in magnitude, but in the time at which it occurred. Some proteins, such as $1,2,5,12,21,28$, and 30 , reached their peak at 1 week after the lesion, $4,13,14$, and 19 at $1-2$ weeks, 8, 9, $10,15,17$, and 19 at 2 weeks, and the remainder at later times. Most frequently, a maximum increase of 10 - to 30 -fold was observed. A much larger increase, 80 - to 90 -fold, was seen for $\alpha$ - and $\beta$-tubulin (25 and 26), as well as for 4 . Labeling in some proteins (the tubulins and actin, as well as 7, 16, and 18) remained significantly elevated even at 12 weeks.

\section{Axonal transport in the new axon segments}

Changes in total transported protein labeling in the regenerating axon sements were determined in experiments in which the optic nerve was lesioned close to the eye and a $24 \mathrm{hr}$ labeling interval was used (Fig. 4B). During the first week, total labeling of transported protein was relatively high (i.e., several times higher than the normal level), even though axonal outgrowth was just beginning (McQuarrie and Grafstein, 1981). The amount increased until 2 weeks, then remained nearly constant at about $8 \times$ normal until 5 weeks, and declined thereafter, reaching approximately twice normal by 12 weeks, when the protein content of the nerve segment had nearly returned to normal (Perry et al., 1985).

The 2D-gel fluorographic patterns of the transported proteins from the new axon segments were not qualitatively different from those for the original axon segments. Quantitative analysis (see lower graphs in Figs. 8-12) revealed that the various proteins differed in the time course and magnitude of the changes 




Figure 7. Labeling of individual transported proteins in new axon segments during regeneration following optic nerve lesion. The contribution of each protein spot is shown as a percentage of the total summed label in the analyzed proteins ( $24 \mathrm{hr}$ labeling). The proteins have been arranged in the order of their relative contributions to the labeling in normal nerves (from sham-operated animals), with the protein showing the largest normal value at the top of the graph and the least intensely labeled protein at the bottom. The order of proteins from the bottom is $30,12,20,14,15,19,29,3,21,22,13,7,17,1,18,4,2,5,10,8$, and 9. The cytoskeletal proteins (25-27) have been omitted because data for all time points were not available; however, the maximum contribution of all 3 combined, which was seen 1 week after the lesion, was only $14 \%$ of the total.

\begin{tabular}{llc}
\hline Table 2. & Tract-lesion paradigm: 6 hr labeling during regeneration \\
Spot no. & 2 d/Normal & Peak/normal \\
\hline 1 & 0.6 & 12.7 \\
2 & 1.3 & 10.0 \\
3 & $2.8^{*}$ & 3.5 \\
4 & $5.7^{*}$ & 185.0 \\
5 & $1.6^{*}$ & 5.2 \\
6 & $-^{a}$ & 17.6 \\
7 & 1.3 & 12.1 \\
8 & $2.6^{*}$ & 16.5 \\
9 & - & 15.9 \\
10 & - & 127.0 \\
12 & 1.2 & 5.0 \\
13 & $3.9^{*}$ & 13.7 \\
15 & 2.2 & 69.0 \\
17 & $3.0^{*}$ & 35.9 \\
18 & 1.1 & 4.4 \\
19 & 2.1 & 45.4 \\
25 & 0.6 & 10.0 \\
26 & 0.8 & 8.7 \\
27 & 1.0 & 5.2 \\
28 & $2.4^{*}$ & 28.7 \\
29 & 3.0 & 12.7 \\
30 & 2.7 & 24.7 \\
\hline & & \\
\hline
\end{tabular}

$a$ Values that could not be obtained because the spots were too faint on the fluorographs from the regenerating nerves.

${ }^{*} p<0.05$ by Student's 2 -tailed $t$ test for $2 \mathrm{~d}$ values. Peak values are all statistically significant.

\begin{tabular}{lcc}
\hline Table 3. & Tract-lesion paradigm: 24 hr labeling during regeneration \\
Spot no. & 2 d/Normal & Peak/normal \\
\hline 1 & 2.2 & 19.6 \\
2 & $4.0^{*}$ & 10.7 \\
3 & $3.5^{*}$ & 14.9 \\
4 & 1.7 & 81.2 \\
5 & $5.0^{*}$ & 6.2 \\
6 & 3.3 & 27.6 \\
7 & - & 19.2 \\
8 & 3.3 & 11.6 \\
9 & 3.2 & 28.1 \\
10 & 2.7 & 29.2 \\
12 & - & 4.6 \\
13 & $3.7^{*}$ & 14.8 \\
14 & $(6)^{*}$ & $(49.2)$ \\
15 & 0.8 & 18.0 \\
16 & - & 28.7 \\
17 & $2.7^{*}$ & 18.4 \\
18 & $2.1^{*}$ & 9.9 \\
19 & - & 51.7 \\
20 & - & 7.6 \\
21 & $(2)$ & $(7.9)$ \\
22 & $(3)$ & $(22.2)$ \\
25 & 3.5 & 91.2 \\
26 & $3.9^{*}$ & 82.6 \\
27 & $2.3^{*}$ & 13.4 \\
28 & $4.3^{*}$ & 19.5 \\
29 & $2.9^{*}$ & 14.0 \\
30 & 4.4 & 14.1 \\
\hline & 5 &
\end{tabular}

a Parentheses indicate values that could only be approximated because the labeling in normal nerves was too low for reliable measurement.

* See Table 2.

seen during regeneration. A maximum increase on the order of 5- to 25-fold was found for most of the proteins (Table 4), occurring at a time that varied between 2 and 8 weeks for different proteins. However, protein no. 4 again showed an exceptionally large change. Reaching its maximum at 5 weeks, it became the most intensely labeled protein of the population, accounting for over $20 \%$ of the total radioactivity in the analyzed spots-almost twice as much as any of the other proteins (Table 4; Fig. 7). Most of the proteins showed a large decline in labeling between 8 and 12 weeks, but even at 12 weeks many still contained $5 \times$ as much label as control nerves.

\section{Correlation between observations in original and in new axon segments}

For most of the analyzed proteins, the changes in the new axon segments were quite different than those in the original segments. However, when the various proteins were grouped according to the time course of changes in the original axon segments (tract-lesion experiments with $24 \mathrm{hr}$ labeling), it was found that each group showed a characteristic pattern of change in the new axon segments as well. This has led us to tentatively separate the proteins into the following classes with the features described:

Class $A$ (protein nos. 1, 2, 5, 12, 21, 28, and 30; Fig. 8)These proteins showed peak labeling in the original axon segments at 1 week after the lesion and a slow buildup of labeling 
in the new axon segments, reaching a relatively high level (equal to or exceeding the maximum level seen in the original axon segments). The peak in the new axon segments occurred at either 5 weeks (Class A1; Fig. 8, upper row) or 8 weeks (Class A2; Fig. 8 , lower row). (No. 28 is included in this class on the basis of the pattern of changes in the original axon segments; it cannot be assigned with certainty to $\mathrm{A} 1$ or $\mathrm{A} 2$ since the 8 week value for the new axon segments was not available.)

Class $B$ (protein nos. 8-10, 15, 17, and 19; Fig. 9)-These proteins showed a sharp peak in the original axon segments at 2 weeks after the lesion, and only a relatively small amount of labeling in the new axon segments, with an initial peak at 2 weeks and a second elevation at 5 weeks. At least 3 of the proteins of this class (8-10) are glycoproteins, as suggested by their multiple spotting pattern, as well as by their incorporation of ${ }^{14} \mathrm{C}$-glucosamine (E. Antonian and B. Grafstein, unpublished observations). These 3 proteins are prominent transport constituents: With $24 \mathrm{hr}$ labeling, the 3 combined represented about $40 \%$ of the total label in the investigated proteins in control nerves (Table 1) and about $25 \%$ of the total in the new axon segments at the height of regeneration (Table 4).

Class $C$ (protein nos. 3, 4, 13, 14, and 29; Fig. 10). The changes in these proteins resembled those of Class A, except that the initial peak in the old axon segments occurred a few days later, i.e., between 1 and 2 weeks, and labeling of the new axon segments increased in 2 phases, reaching an initial plateau at 1-3 weeks and then rising to a peak at 5 weeks that was usually close in height to that in the original axon segments. [Even though the labeling of protein no. 3 in the original segments remained relatively constant from 1 to 3 weeks in this experiment, it showed a typical Class C pattern in another experiment (G. W. Perry, unpublished observations).]

Class $D$ (protein nos. 7, 16, 18, 20, and 22; Fig. 11). These proteins showed a relatively long-lasting increase, persisting until at least 5 weeks in both the original and new axon segments, and a moderately high level of labeling in the new segments, which was somewhat delayed in appearance, usually not beginning until 2 weeks or later. Some of the members of this class $(7,16$, and 18$)$ resembled one another in showing a considerably elevated level of labeling in the original axon segments even at 12 weeks after the lesion.

Class $E$ (Fig. 12). This consisted of the cytoskeletal proteins $\alpha$ - and $\beta$-tubulin and actin. Their characteristics were a relatively slow increase in labeling in the original axon segments, not reaching its maximum until 3 weeks, and a relatively low level of labeling in the new axon segments, which increased until 2 weeks and then remained relatively constant.

\section{Discussion}

To which axonal transport groups do the investigated proteins belong?

The relative transport velocities of different proteins may be estimated from the changes in labeling that they show at different times after the application of precursor. The transport velocities of the proteins examined in the present study would be in excess of $20 \mathrm{~mm} / \mathrm{d}$ for $6 \mathrm{hr}$ labeling and $5 \mathrm{~mm} / \mathrm{d}$ for $24 \mathrm{hr}$ labeling, if we assume a minimum effective transport path of $5 \mathrm{~mm}$ from the back of the eye to the center of the nerve sample; velocities of 8 and $2 \mathrm{~mm} / \mathrm{d}$ for 6 and $24 \mathrm{hr}$ labeling, respectively, would be the minimum required for proteins just to reach the nerve sample. These velocities, considered in relation to the maximum velocity of $60-100 \mathrm{~mm} / \mathrm{d}$ that is normally seen in this system
Table 4. Nerve-lesion paradigm: 24 hr labeling during regeneration

\begin{tabular}{|c|c|c|c|}
\hline Spot no. & Peak/normal & $\begin{array}{l}\text { Time of peak } \\
\text { (weeks) }\end{array}$ & $\begin{array}{l}\text { Percent of } \\
\text { total label } \\
\text { in analyzed } \\
\text { proteins } \\
\text { (at } 5 \text { weeks) }\end{array}$ \\
\hline 1 & 25.5 & 5 & 10.8 \\
\hline 2 & 8.3 & 8 & 5.4 \\
\hline 3 & 19.9 & 5 & 3.2 \\
\hline 4 & 36.7 & 5 & 22.1 \\
\hline 5 & 4.9 & 5 & 4.9 \\
\hline 6 & 12.4 & 8 & 2.5 \\
\hline 7 & 16.0 & 5 & 3.9 \\
\hline 8 & 4.7 & 2 & 4.7 \\
\hline 9 & 8.7 & 2 & 12.3 \\
\hline 10 & 13.4 & 2 & 9.7 \\
\hline 12 & 22.3 & 8 & 0.6 \\
\hline 13 & 10.4 & 5 & 1.6 \\
\hline 14 & $(52)^{a}$ & 5 & 2.0 \\
\hline 15 & 14.6 & 2 & 1.6 \\
\hline 16 & 25.6 & 5 & 3.9 \\
\hline 17 & 6.9 & 2 & 1.6 \\
\hline 18 & 8.3 & 5 & 4.8 \\
\hline 19 & 15.2 & 2 & 1.9 \\
\hline 20 & 9.8 & 3 & 1.0 \\
\hline 21 & (9.4) & 8 & 0.9 \\
\hline 22 & $(9.3)$ & 8 & 1.1 \\
\hline 25 & 8.8 & 2 & 2.3 \\
\hline 26 & 6.7 & 2 & 1.3 \\
\hline 27 & 4.4 & 2 & 3.0 \\
\hline 28 & 6.9 & 5 & 1.5 \\
\hline 29 & 10.2 & 5 & 1.3 \\
\hline 30 & 22.6 & 8 & 1.0 \\
\hline
\end{tabular}

a Parentheses indicate values that could only be approximated because of low labeling in the normal nerves.

(Grafstein and Forman, 1980), would probably be equivalent to transport groups I and II for the $6 \mathrm{hr}$ labeling and to groups I-III for the $24 \mathrm{hr}$ labeling (Skene and Willard, 1981c), i.e., involving primarily relatively rapidly transported, rather than slowly transported, proteins in either case. Proteins that showed significantly greater labeling at $6 \mathrm{hs}$ than at $24 \mathrm{hr}$ in the original axon segments $(1,2,3,5,28$, and possibly 6$)$ are probably constituents of groups I and II. They are presumably rapidly removed from the nerve by further anterograde transport to the axon terminals, by retrograde transport to the cell body, or by metabolic degradation. Greater labeling at $24 \mathrm{hr}$ than at $6 \mathrm{hr}$, on the other hand (as is characteristic of $7,10,14,16,18,20$, 21 , and 22), most probably indicates that these proteins are somewhat more slowly transported, i.e., constituents of fasttransport groups II and III (Skene and Willard, 1981c). Some, however, may be transported at the fastest velocity but relatively slowly released from the cell body, as appears to be characteristic of at least some glycoproteins (Specht and Grafstein, 1976; Whitnall et al., 1982). Those that do not change labeling significantly between 6 and $24 \mathrm{hr}$ might preferentially include members of group II or members of group I that have been deposited in the axon rather than being conveyed directly to the axon terminals (Stone and Hammerschlag, 1983) and then are relatively slowly metabolized. 


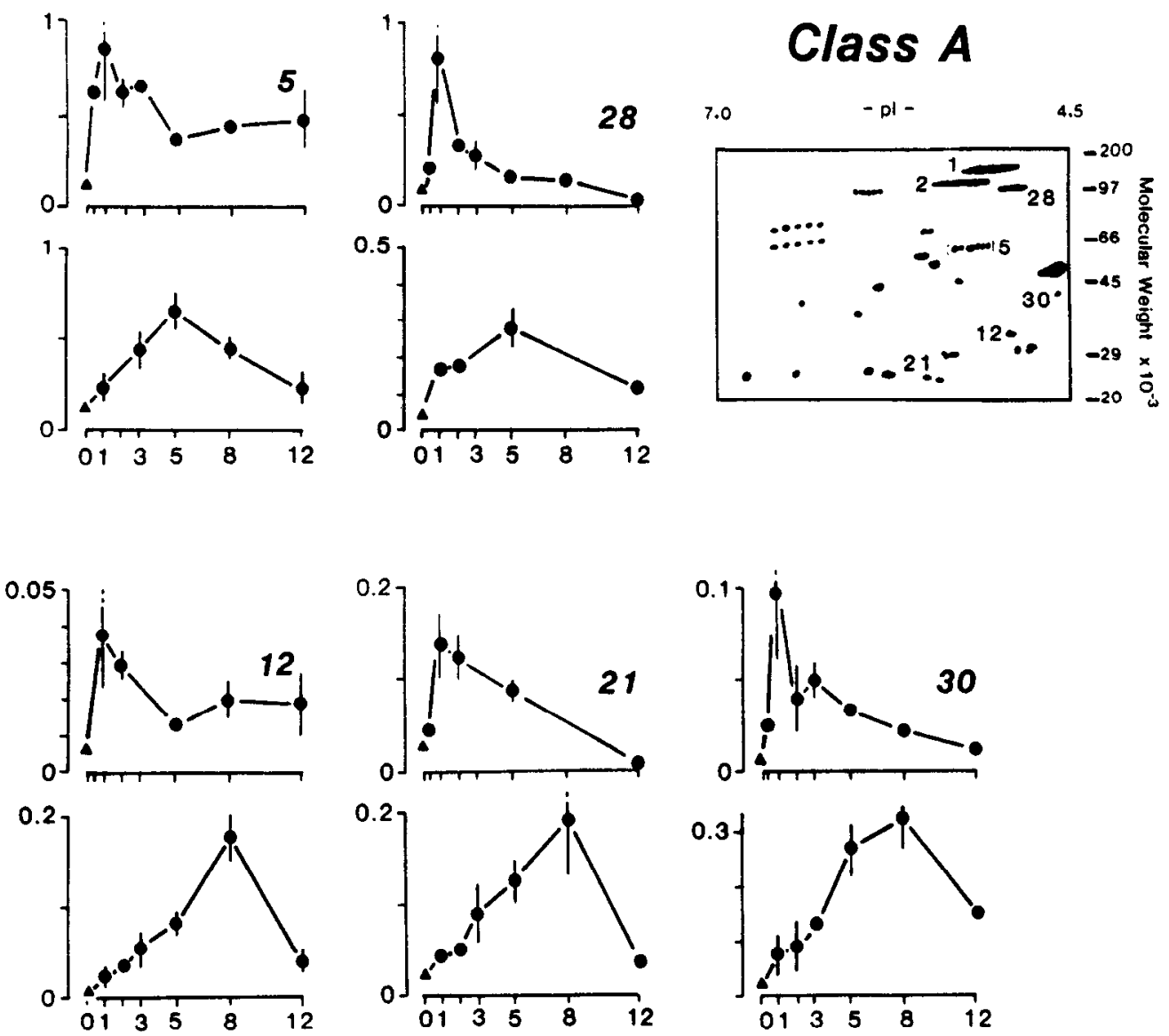

Figure 8. Classification of individual transported proteins (numbered as in maps in Figures 1 and 2 and shown in insets in Figures 8-12). Proteins have been grouped on the basis of the temporal sequence of changes during regeneration in original axon segments. For each protein, the incorporated radioactivity observed in the original axon segments (upper panel) and new axon segments (lower panel) is shown at various times after the lesion (times given in weeks). Ordinate values as in Figure 5. Data represent the mean \pm SEM of 3-6 determinations (see legend to Fig. 5).

The labeling of tubulin and actin under the conditions used in the present study is surprising, since these elements are usually considered to be conveyed by slow axonal transport (Grafstein and Forman, 1980). In the goldfish optic axons, the bulk of the tubulin has been assigned, like actin (McQuarrie, 1983), to slow component B (Hoffman and Lasek, 1975) or group IV (Lorenz and Willard, 1978; Skene and Willard, 1981c), with a transport velocity of about $0.2-0.4 \mathrm{~mm} / \mathrm{d}$ in normal axons and $1-2 \mathrm{~mm} / \mathrm{d}$ in regenerating axons (Grafstein and Murray, 1969; McQuarrie and Grafstein, 1982b; McQuarrie, 1983). The velocity in excess of $2 \mathrm{~mm} / \mathrm{d}$ that is applicable to the transported tubulin and actin in the present study is therefore higher than the value that can be ascribed to slow transport. One possible source for the labeling of tubulin and actin that we observed might be local synthesis of proteins in the optic nerve, presumably representing incorporation into the glial cells of labeled precursor that has diffused from the eye. However, we believe that this is unlikely to be the case for the following reasons: (1) Other prominent proteins that are locally synthesized in the nerve (Perry et al., 1985) were not visibly labeled in the present study; (2) changes in local synthesis of actin and tubulin during regeneration, as determined by studies on excised nerves, showed a different time course from that seen for their labeling in the present study (G. W. Perry, unpublished observations); (3) most of the $24 \mathrm{hr}$ labeled tubulin and actin disappeared when the axons degen- erated (E. Antonian, G. W. Perry, and B. Grafstein, unpublished observations), indicating an intra-axonal location. It is possible that a small proportion of axonal tubulin and actin might be transported at a greater velocity than is conventionally accepted for slow transport, although the previous evidence for fast transport of tubulin is contradictory (e.g., Stone et al., 1978; Stromska et al., 1983). Conceivably, the faster-moving tubulin might be a separate membrane-bound fraction that plays a special role in the axon, for example, in relation to synaptic vesicles or other membrane organelles (Zisapel et al., 1980; Bernier-Valentin et al., 1983; Schnapp et al., 1985). Our own studies thus far suggest that the increase in labeling of the rapidly appearing fraction of tubulin and actin occurring during regeneration is about equal to that seen for the bulk of these materials arriving by slow transport (G. W. Perry and E. Antonian, unpublished observations).

\section{Significance of increased protein labeling}

Our observation of an increase in labeling of total fast-transported protein in the original axon segments during regeneration was consistent with the observations of McQuarrie and Grafstein (1982a) in goldfish optic axons and also with the findings of Skene and Willard (1981a) on transport groups I and II in toad optic axons. With either a 6 or $24 \mathrm{hr}$ labeling interval, we found a peak in ${ }^{3} \mathrm{H}$-proline incorporation into total transported 

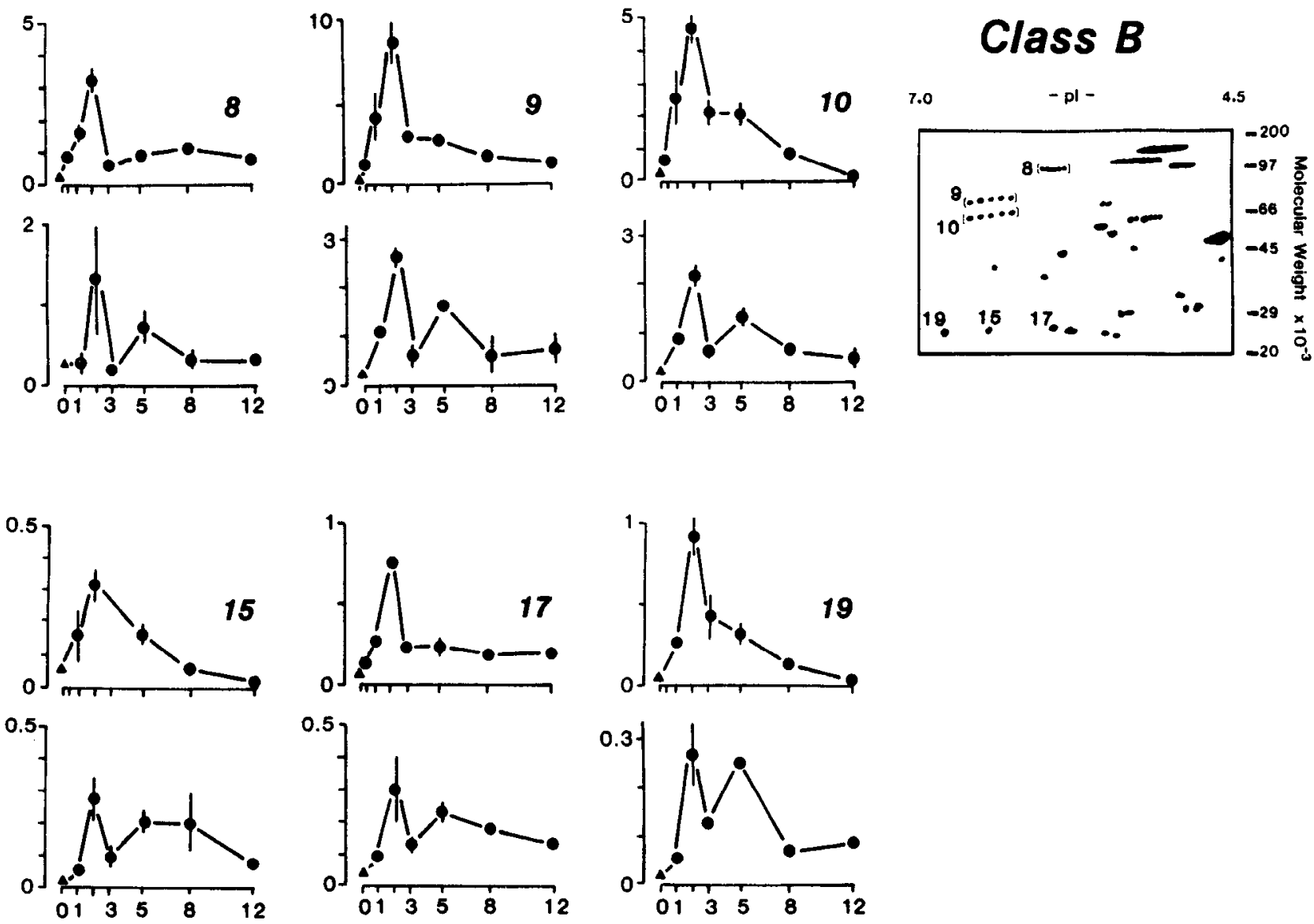

Figure 9. See legend to Figure 8.

protein at 2 weeks and continuous recovery thereafter, requiring at least 12 weeks. This closely followed the time course of increased incorporation of radioactively labeled amino acid into protein in the cell body (McQuarrie and Grafstein, 1982a). There is also other evidence of an increase in protein synthesis in the goldfish retinal ganglion cells during regeneration (reviewed by Grafstein, 1986). Thus the most obvious cause of the increased labeling observed in the present study was increased synthesis of axonally transported proteins.

In addition to the rate of synthesis, however, there were a number of other changes that could have influenced the labeling of axonal proteins after a lesion. One of these was obviously the rate of turnover of the transported material, and the following factors may have also played a role:

1. There was damming of transported proteins in the shortened axons (McQuarrie, 1977; Whitnall, 1980), resulting in a large accumulation of labeled protein at the cut tips of the axons, and a considerable increase in labeling all along the length of nerve between the lesion and the eye (McQuarrie, 1977).

2. The velocity of fast axonal transport increased (Grafstein and Murray, 1969; McQuarrie and Grafstein, 1982a).

3. There was a shift toward a higher proportion of extracellular amino acid as the precursor for protein synthesis (Whitnall and Grafstein, 1981), so that the specific activity of the precursor pool was increased.

4. There was an alteration in the routing of material within the cell body (Whitnall and Grafstein, 1982, 1983), and the various pools of proteins available for transport (Specht and Grafstein, 1976) may be altered in size.
5. The release of material from the cell body into the axon may have been altered (Grafstein and Alpert, 1976; McQuarrie and Grafstein, 1982a; Aletta and Goldberg, 1984).

6. There may have been an increased rate of deposition of the labeled material (Whitnall and Grafstein, 1982, 1983).

7. Posttranslational modification of transported proteins may have occurred, including amino acid addition (Chakraborty et al., 1986).

8. Changes in the dynamics of retrograde transport or in the linkage between anterograde and retrograde transport may have occurred during the course of regeneration (Whitnall et al., 1982; Bisby, 1984) as the new axon segments changed in morphology and function.

Some of the above mechanisms might be expected to have had a more-or-less uniform effect on the whole population of transported proteins. However, the differences that we observed among various proteins during regeneration suggested that mechanisms that affected the proteins selectively must have been involved in at least some of the changes. Further investigation will be required to determine which factors, in addition to an increase in protein synthesis, had a significant influence on the labeling patterns.

In the new axon segments, the deposition of the transported material, which presumably contributed to the increasing volume of the new segments, would be an important determinant of how much label was present. The initial increase in labeling in these segments during the first 2 weeks after an optic nerve lesion corresponded to the period of active axonal elongation (McQuarrie, 1985). The total labeling of transported material 

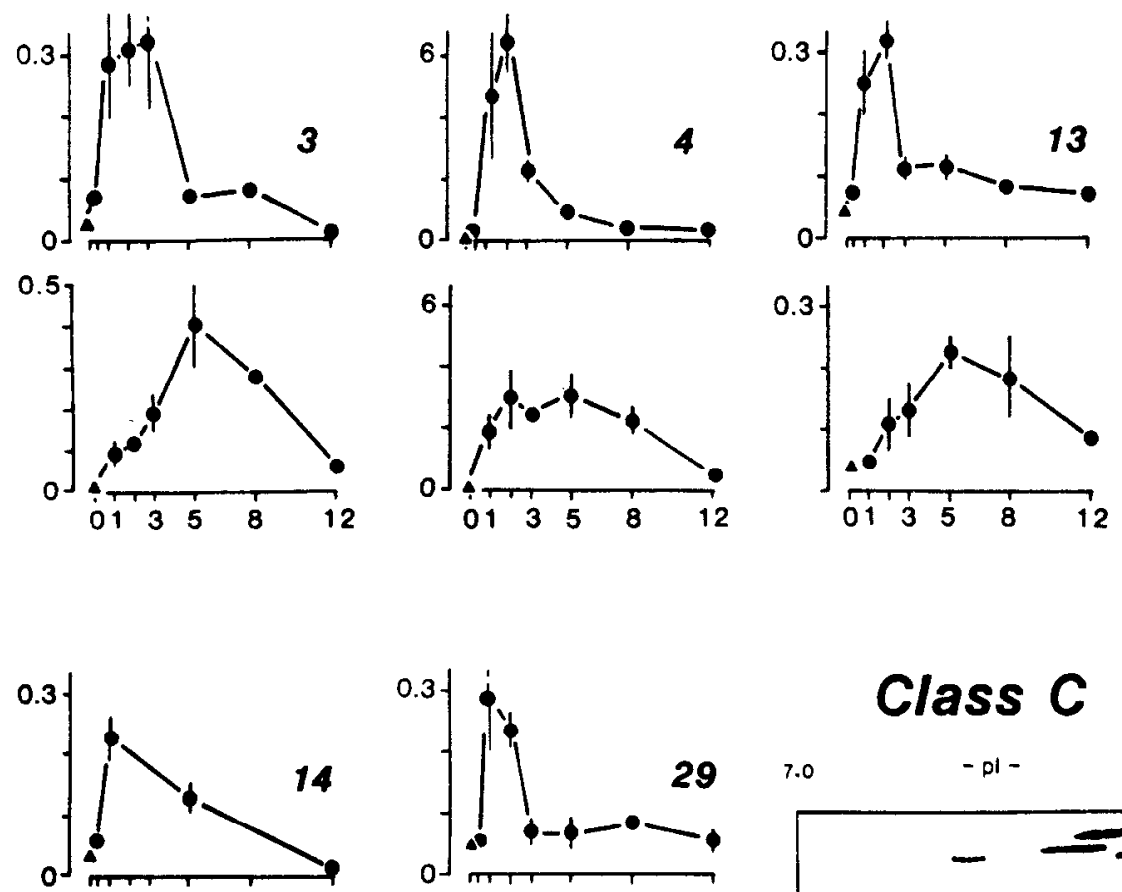

Class C
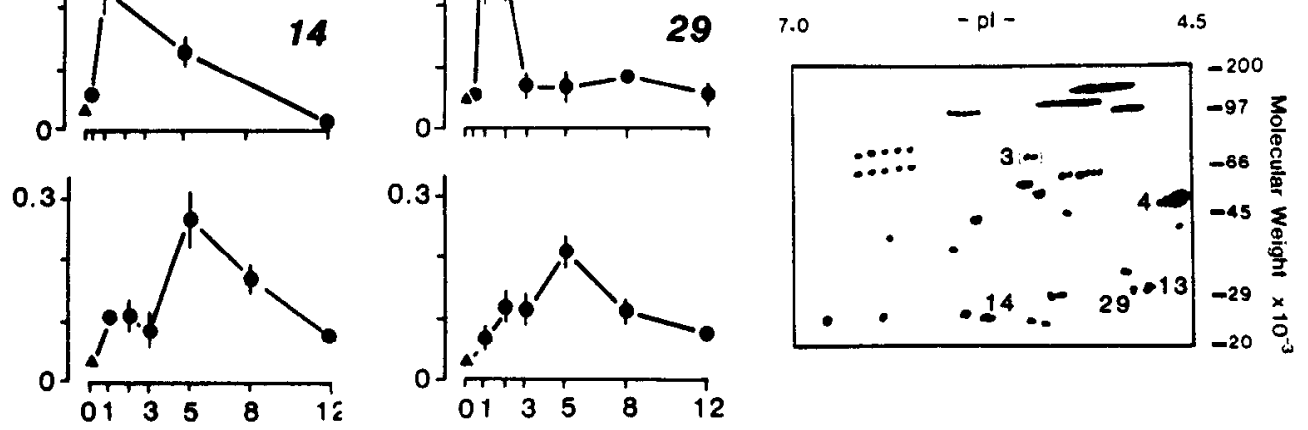

Figure 10. See legend to Figure 8.

remained almost constant from 2 to 5 weeks, which was a time of profuse formation of intratectal axon branches (Murray and Edwards, 1982). Establishment of synaptic connections (Schmidt et al., 1983; Stuermer and Easter, 1984) also occurred at this time, continuing until at least 12 weeks (Murray and Edwards, 1982). Total labeling of fast-transported protein, as well as the labeling of many individual proteins, showed a sharp decline after 5 weeks. Since the regenerating axons continue to increase in both number and diameter until at least 12 weeks (Murray, 1982), it appears that fast-transported materials were less important for axonal maturation than for outgrowth. By contrast, slow axonal transport, especially of neurofilaments, apparently would make an important contribution to the increase in axon size (Hoffman et al., 1984).

\section{Patterns of labeling of individual proteins}

All the transported proteins that we analyzed were found to increase their labeling during regeneration. Increased labeling was also seen in most of the proteins examined by Skene and Willard (1981a) and Szaro et al. (1984, 1985) in regenerating amphibian optic nerve. None of the proteins we analyzed showed an increase in labeling that was confined to either the early or late stages of regeneration, i.e., that might be associated with only a particular stage of growth. We also found no proteins that showed a sustained decrease in labeling during regeneration. This would be consistent with the observation that proteins that are normally concentrated in nerve terminals are synthesized in abundance in growing neurons even before the terminals are formed (Katz et al., 1985). [Skene and Willard (1981a) and Szaro et al. $(1984,1985)$ reported that a few proteins in amphibian optic nerves showed decreased labeling with ${ }^{35} \mathrm{~S}$-methionine during regeneration, but this decrease was measured relative to the labeling of the total population of proteins.]

We have tentatively separated the transported proteins into 5 different classes showing different temporal patterns of labeling in the original and new axon segments. These patterns could be generated through the interplay of the various factors discussed in the section above. It is possible that the proteins in any 1 class could be subject to the same regulatory factors and could represent functionally related proteins. One interesting possibility is that they might be localized within the same structural constituent or organelle. Recent studies in frog sensory axons have suggested that there may be at least 2 distinct populations of fast-transported proteins, which may be conveyed by different structural entities (Rulli and Wilson, 1985).

A number of cellular structures are known to change significantly during regeneration. For example, there is increased turnover of proteins in the plasma membrane even in the intact portions of the neuron (Whitnall and Grafstein, 1982); there is a tremendous increase in the production of smooth membranes (Whitnall and Grafstein, 1983), and there is a proliferation of dense cored vesicles (Murray, 1976; Whitnall and Grafstein, $1982,1983)$. There are also likely to be changes in some structures associated with synaptic transmission (Reis et al., 1978). 

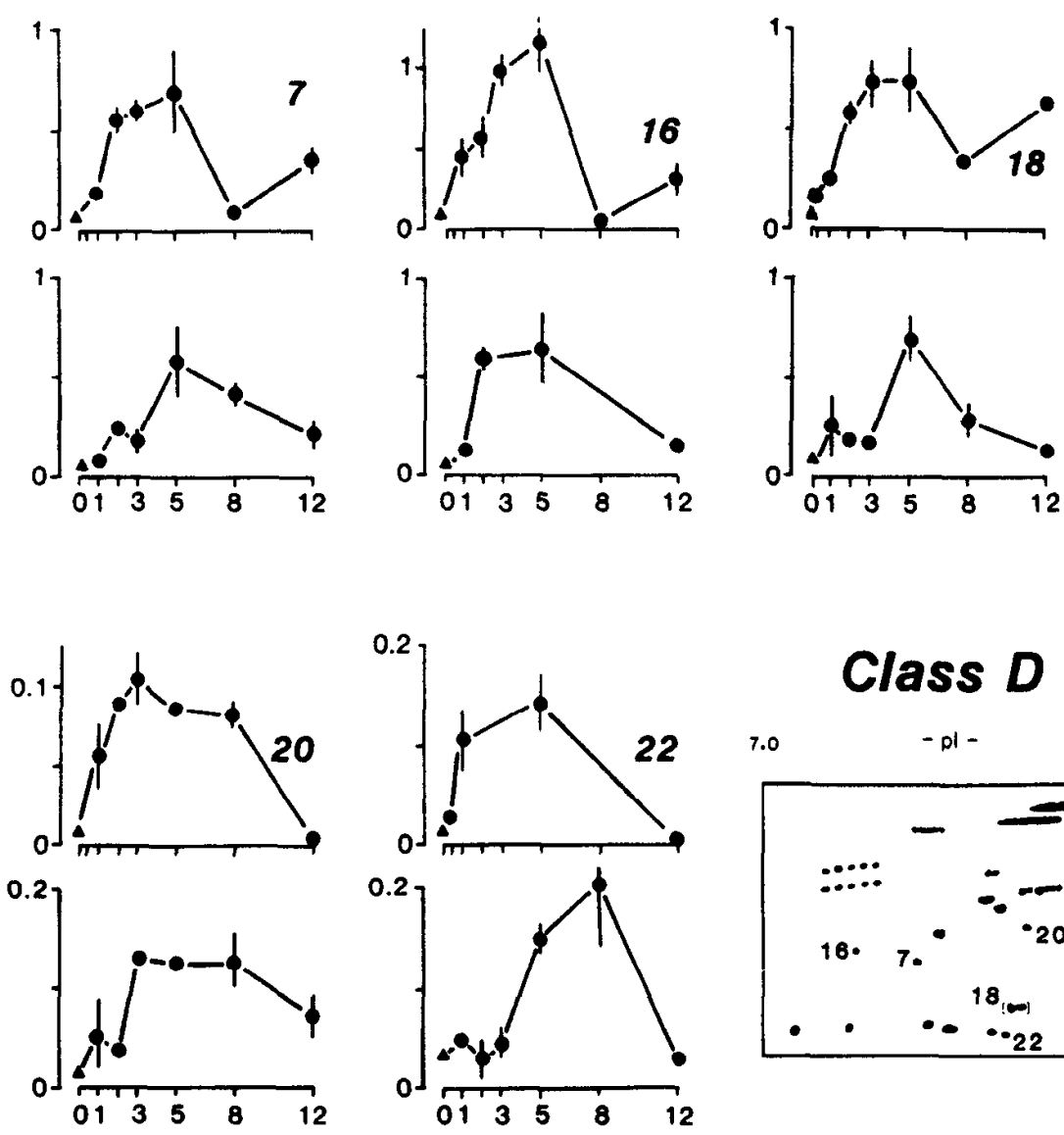

Class D
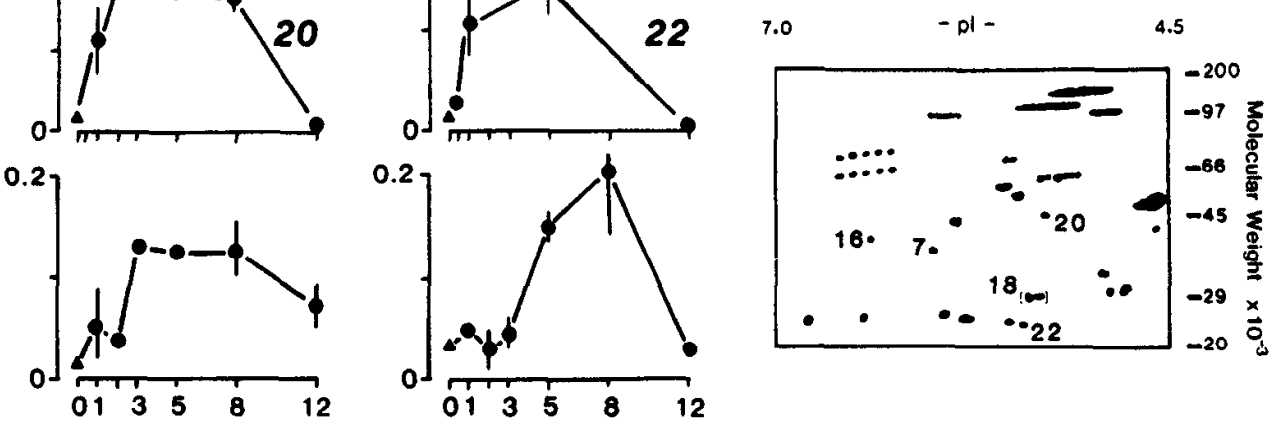

Figure 11. See legend to Figure 8.
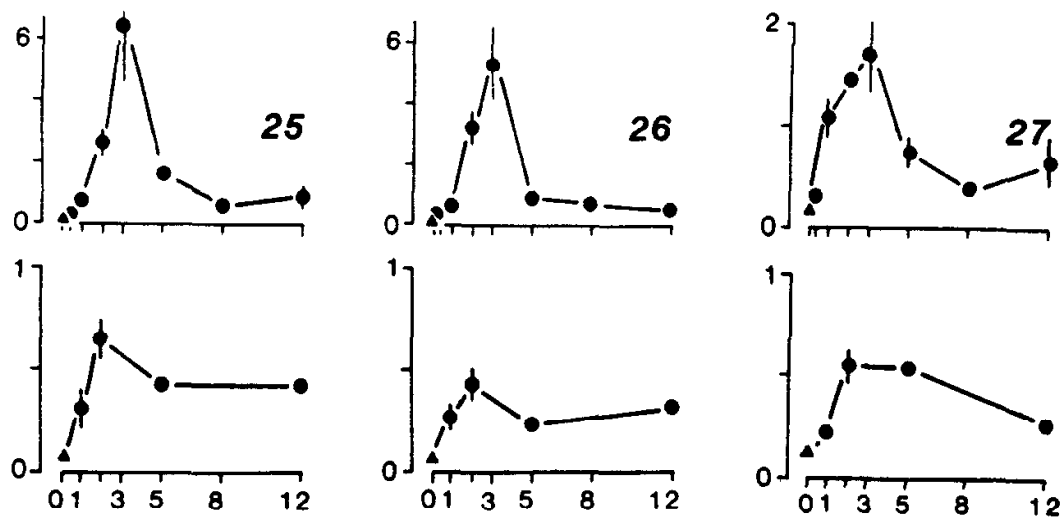

\section{Class E}



Figure 12. See legend to Figure 8. 
It is conceivable that some of these cell constituents correspond to the various classes of transported proteins, but further information is required before any clear identifications can be made.

The only group of proteins of known identity is Class $\mathrm{E}$, which consists of the cytoskeletal proteins. They showed a pattern of changes unlike that of proteins in other classes, with a relatively slow increase in labeling in the original axon segments, reaching a peak at 3 weeks. Recovery was still incomplete at 12 weeks, especially in the case of $\alpha$-tubulin. In the new axon segments, incorporation remained relatively constant after about 2 weeks, representing a relatively low level compared to the peak incorporation into the original segments. However, when the smaller proportion of nerve cross section occupied by axons in the new segment (Murray, 1982) is allowed for, labeling of the cytoskeletal elements in the new axon segments was comparable to that in the original segments from about 5 weeks onward.

Another protein that can be recognized as an identifiable entity is protein no. 4 , which we have designated protein B in another context (Perry et al., 1985). It corresponds to the protein of approximately $45 \mathrm{kDa} M_{\mathrm{r}}$ that has been investigated by Benowitz et al. (1981; Benowitz and Lewis, 1983) and other workers (Heacock and Agranoff, 1982). It is a largely membranebound protein (E. Antonian, G. W. Perry, and B. Grafstein, unpublished observations), which can become phosphorylated in the course of axonal transport (Larrivee and Grafstein, 1987) as well as in the axon terminals (L. Benowitz, personal communication). It closely resembles GAP-43, which was originally identified in regenerating toad optic nerve by Skene and Willard $(1981 \mathrm{a}, \mathrm{c})$. The same protein apparently undergoes increased synthesis in mammalian neurons with axons that are growing in the course of development or regeneration, but not in CNS neurons that fail to regenerate after axotomy (Skene and Willard, 1981b; Willard and Skene, 1982; Skene 1984; Jacobson et al., 1986; Kalil and Skene, 1986). A protein of about the same molecular weight and $\mathrm{p} I$, which is subject to $\mathrm{Ca}^{2+}$-dependent phosphorylation, has been found to be enriched in growth cones from fetal rat brain (Katz et al., 1985; McGuire et al., 1985). A similar protein localized in axon terminals of adult mammalian brain (Oestreicher et al., 1981; Jacobson et al., 1986), which has been designated B50 (Zwiers et al., 1980) or F1 (Routtenberg et al., 1985), has been shown to increase its phosphorylation under the influence of ACTH (Zwiers et al., 1980; Oestreicher et al., 1981), during development (Jacobson et al., 1986), and in the coursc of long-term potentiation in the hippocampus (Routtenberg et al., 1985).

In the present study, protein no. 4, like GAP-43 in toad optic nerve (Skene and Willard, 1981a), was found to be synthesized and axonally transported at a low level in the normal retinal ganglion cells, but showed greatly enhanced labeling during regeneration. Its labeling was maximal at 1-2 weeks, then decreased abruptly, but still remained significantly higher than normal until at least 8 weeks. The prominence of protein no. 4 in the new axon segment throughout regeneration, as reflected in its large contribution to the amount of transported label, and also its greatly increased abundance (Benowitz and Lewis, 1983; Perry et al., 1985), suggests that it may be an important structural element of the growing axon, and not confined to the growth cone. GAP-43 has been reported to be associated with plasma membrane in toad optic nerve (Skene and Willard, 1981d). The changes that it undergoes during regeneration may reflect a greatly increased turnover of plasma membrane in re- generating neurons (Whitnall and Grafstein, 1983), and possibly a change in the plasma membrane composition. Conceivably protein no. 4 in the goldfish may be associated with the smooth membrane system, which shows a dramatic proliferation beginning very early in regeneration (Whitnall and Grafstein, 1982, 1983), and which is a prominent feature in growth cones of goldfish optic axons (Gambetti et al., 1978; Lanners and Grafstein, 1980) and in particles that can be conveyed along the emerging axons at the velocity of fast transport (Koenig et al., 1985).

\section{General significance of the changes during regeneration}

We have not found any evidence for the synthesis of new fasttransported proteins during regeneration, but rather increases of various magnitudes in all of the proteins that are rapidly transported in the normal goldfish optic nerve. Moreover, recent work indicates that even when protein synthesis has been blocked, axonal outgrowth can be maintained for about a week, but is arrested beyond that time (Sparrow et al., 1985; Grafstein et al., 1986). These findings lead us to conclude that goldfish retinal ganglion cells normally contain the total array of proteins required for the initial outgrowth of thcir axons, but that the increased synthesis of all these proteins that occurs following axonal injury is essential for the maintenance of regeneration.

Our results are generally in agreement with the studies by Skene and Willard on toad optic nerve (1981a-d; Willard and Skene, 1982; Skene, 1984). As in the present study, these workers reported a widespread increase in labeling of transported proteins during regeneration; they emphasized, however, that some proteins that were only labeled to a small degree under normal circumstances showed a massive increase in labeling during regeneration. They further suggested that these proteins, which they designated "GAPs," might be required to perform functions specifically required for nerve growth and regeneration.

Our own results indicate that the pattern of changes in a protein (4 in the goldfish) that corresponds to one of the putative GAPs (GAP-43) is only quantitatively and not qualitatively different from that of a number of other proteins. It appears to be, therefore, one of a class of proteins that may be coregulated during regeneration and that may also be interrelated in their functional role. Moreover, the fact that there are a number of such classes, which differ in their labeling patterns, indicates that even the less intensely labeled proteins do not simply show a nonspecific uniform incrcase in labeling, but are differentially regulated. This would be consistent with the idea that there may be multiple regulatory systems that control the metabolic changes evoked by axotomy (Benowitz et al., 1981; Skene and Willard, 1981a). Whether the initiation of the axotomy-evoked reaction involves a simultaneous activation of all these systems, or there is a sequence in which one kind of change leads to another, is not yet clear, since the mechanisms involved in the initiation of the reaction are still obscure (Willard and Skene, 1982; Forman, 1983; Grafstein, 1983).

\section{References}

Aletta, J. M., and D. J. Goldberg (1984) Routing of transmitter and other changes in fast axonal transport after transection of one branch of the bifurcate axon of an identified neuron. J. Neurosci. 4: 18001808.

Benowitz, L., and E. R. Lewis (1983) Increased transport of 44,000 to 49,000 dalton acidic proteins during regeneration of the goldfish optic nerve: A 2-dimensional analysis. J. Neurosci. 3: 2153-2163.

Benowitz, L. I., V. E. Shashoua, and M. G. Yoon (1981) Specific 
changes in transported proteins during regeneration of the goldfish optic nerve. J. Neurosci. 1: 300-307.

Bernier-Valentin, F., D. Aunis, and B. Rousset (1983) Evidence for tubulin-binding sites on cellular membranes: Plasma membranes, mitochondrial membranes, and secretory granule membranes. J. Cell Biol. 97: 2709-2716.

Bisby, M. A. (1984) Retrograde axonal transport and nerve regeneration. In Axonal Transport in Neuronal Growth and Regeneration, J. S. Elam and P. Cancalon, eds., pp. 45-67, Plenum, New York.

Bonner, W. M., and R. A. Laskey (1974) A film detection method for tritium-labelled proteins and nucleic acids in polyacrylamide gels. Eur. J. Biochem. 46: 83-88.

Burmeister, D. W., G. W. Perry, and B. Grafstein (1983) Target regulation of the cell body reaction during regeneration of goldfish retinal ganglion cells. Soc. Neurosci. Abstr. 9: 694.

Chakraborty, G., T. Leach, M. F. Zanakis, and N. A. Ingoglia (1986) Post translational protein modification by amino acid addition in regenerating optic nerves of goldfish. J. Neurochem. 46: 726-732.

Forman, D. S. (1983) Axonal transport and nerve regeneration: A review. In Spinal Cord Reconstruction, C. C. Kao, R. P. Bunge, and P. J. Reier, eds., pp. 75-86, Raven, New York.

Gambetti, P., N. A. Ingoglia, L. Autilio-Gambetti, and P. Weiss (1978) Distribution of $\left[{ }^{3} \mathrm{H}\right]-\mathrm{RNA}$ in goldfish optic tectum following intraocular or intracranial injection of ${ }^{3} \mathrm{H}$-uridine. Evidence of axonal migration of RNA in regenerating optic fibers. Brain Res. 154: 285300.

Giulian, D., H. Des Ruisseaux, and D. Cowburn (1980) Biosynthesis and intra-axonal transport of proteins during neuronal regeneration. J. Biol. Chem. 255: 6494-6501.

Grafstein, B. (1983) Chromatolysis reconsidered: A new view of the reaction of the nerve cell body to axon injury. In Nerve, Organ, and Tissue Regeneration: Research Perspectives, F. J. Seil, ed., pp. 37-50, Academic, New York.

Grafstein, B. (1986) The retina as a regenerating organ. In The Retina. A Model for Cell Biology Studies, R. Adler and D. Farber, eds., pp. 275-335, Academic, New York.

Grafstein, B., and R. Alpert (1976) Early changes in the metabolism of goldfish retinal ganglion cells following axotomy. Soc. Neurosci. Abstr. 2: 46.

Grafstein, B., and D. Forman (1980) Intracellular transport in neurons. Physiol. Rev. 60: 1167-1283.

Grafstein, B., and M. Murray (1969) Transport of protein in goldfish optic nerve during regeneration. Exp. Neurol. 25: 494-508.

Grafstein, B., D. W. Burmeister, C. M. McGuinness, G. W. Perry, and J. R. Sparrow (1987) Role of fast axonal transport in regeneration of goldfish optic axons. Prog. Brain Res. 71: 113-120.

Heacock, A. M., and B. Agranoff (1982) Protein synthesis and transport in the regenerating goldfish visual system. Neurochem. Res. 7 . 771-778.

Hoffman, P. N., and R. Lasek (1975) The slow component of axonal transport. J. Cell Biol. 66: 351-366.

Hoffman, P. N., J. W. Griffin, and D. L. Price (1984) Control of axon caliber by neurofilament transport. J. Cell Biol. 99: 705-714.

Jacobson, R. D., I. Virág, and J. H. P. Skene (1986) A protein associated with axon growth, GAP-43, is widely distributed and developmentally regulated in rat CNS. J. Neurosci. 6: 1843-1855.

Kalil, K., and J. H. P. Skene (1986) Elevated synthesis of an axonally transported protein correlates with axon outgrowth in normal and injured pyramidal tracts. J. Neurosci. 6: 2563-2570.

Katz, F., L. Ellis, and K. H. Pfenninger (1985) Nerve growth cones isolated from fetal rat brain III. Calcium dependent protein phosphorylation. J. Neurosci. 5: 1402-1411.

Koenig, E., S. Kinsman, E. Repasky, and L. Sultz (1985) Rapid mobility of motile varicosities and inclusions containing $\alpha$-spectrin, actin, and calmodulin in regenerating axons in vitro. J. Neurosci. 5: 715-729.

Lanners, H. N., and B. Grafstein (1980) Effect of a conditioning lesion on regeneration of goldfish optic axons: Ultrastructural evidence of enhanced outgrowth and pinocytosis. Brain Res. 196: 547-553.

Larrivee, D. C., and B. Grafstein (1987) In vivo phosphorylation of axonal proteins in goldfish optic nerve during regeneration. J. Neurochem. 48: 279-283.

Laskey, R. A., and A. D. Mills (1975) Quantitative film detection of ${ }^{3} \mathrm{H}$ and ${ }^{14} \mathrm{C}$ in polyacrylamide slab-gels. Anal. Biochem. 67: 347-352.

Lorenz, T., and M. Willard (1978) Subcellular fractionation of intra- axonally transported polypeptides in the rabbit visual system. Proc. Natl. Acad. Sci. USA 75: 505-509.

McEwen, B. S., and B. Grafstein (1968) Fast and slow components in axonal transport of protein. J. Cell Biol. 38: 494-508.

McGuire, C. B., J. J. Norden, S. S. Bock, and J. A. Freeman (1985) Immunohistochemical localization of a neuronal growth-associated protein (GAP-43) in neonatal rat brain. Soc. Neurosci. Abstr. 11:419.

McQuarrie, I. G. (1977) Axonal regeneration in the goldfish optic system: The role of the nerve cell body. Ph.D. thesis, Cornell University Graduate School of Medical Sciences, New York.

McQuarrie, I. G. (1983) Role of the axonal cytoskeleton in the regenerating nervous system. In Nerve, Organ and Tissue Regeneration. Research Perspectives, F. J. Seil, ed., pp. 51-88, Academic, New York.

McQuarrie, I. G. (1985) Stages of axonal regeneration following optic nerve crush in goldfish: Contrasting effects of conditioning nerve lesions and intraocular acetoxycycloheximide injections. Brain Res. 333: 247-253.

McQuarrie, I. G., and B. Grafstein (1981) Effect of a conditioning lesion on optic nerve regeneration in goldfish. Brain Res. 216: 253264.

McQuarrie, I. G., and B. Grafstein (1982a) Protein synthesis and fast axonal transport in regenerating goldfish retinal ganglion cells. Brain Res. 235: 213-223.

McQuarrie, I. G., and B. Grafstein (1982b) Protcin synthcsis and axonal transport in goldfish retinal ganglion cells during regeneration accelerated by a conditioning lesion. Brain Res. 251: 25-37.

Murray, M. (1976) Regeneration of retinal axons into the goldfish optic tectum. J. Comp. Neurol. 168: 175-196.

Murray, M. (1982) A quantitative study of regenerative sprouting by optic axons in goldfish. J. Comp. Neurol. 209: 352-362.

Murray, M., and M. A. Edwards (1982) A quantitative study of the reinnervation of the goldfish optic tectum following optic nerve crush. J. Comp. Neurol. 109: 363-373.

Murray, M., and B. Grafstein (1969) Changes in the morphology and amino acid incorporation of regenerating goldfish optic neurons. Exp. Neurol. 23: 544-560.

Oestreicher, A. B., H. Zwiers, P. Schotman, and W. Gispen (1981) Immunohistochemical localization of a phosphoprotein (B50) isolated from rat brain synaptosomal plasma membrane. Brain Res. Bull. 6: $145-153$

O'Farrell, P. (1975) High resolution two-dimensional electrophoresis of proteins. J. Biol. Chem. 250: 4007-4024.

Perry, G. W., and D. L. Wilson (1981) Protein synthesis and axonal transport during nerve regeneration. J. Neurochem. 37: 1203-1217.

Perry, G. W., J. Krayanek, and D. L. Wilson (1983) Protein synthesis and rapid axonal transport during regrowth of dorsal root axons. J. Neurochem. 40:1590-1598.

Perry, G. W., D. W. Burmeister, and B. Grafstein (1985) Changes in protein content of goldfish optic nerve during degeneration and regeneration following nerve crush. J. Neurochem. 44: 1142-1151.

Reis, D. J., R. A. Ross, G. Gilad, and T. H. Joh (1978) Reaction of central catecholaminergic neurons to injury: Model systems for studying the neurobiology of central regeneration and sprouting. In Neuronal Plasticity, C. W. Cotman, ed., pp. 197-226, Raven, New York.

Routtenberg, A., D. Lovinger, and O. Steward (1985) Selective increase in phosphorylation of a $47 \mathrm{kDa}$ protein (F1) directly related to long-term potentiation. Behav. Neural Biol. 43: 3-11.

Rulli, R. D., and D. L. Wilson (1985) Proteins in fast axonal transport are differentially transported in branches of sensory nerves. Brain Res. 335: 165-168.

Schmidt, J. T., D. L. Edwards, and C. L. Stuermer (1983) The reestablishment of synaptic transmission by regenerating optic axons in goldfish: Time course and effects of blocking activity by intraocular injection of tetrodotoxin. Brain Res. 269: 15-27.

Schnapp, B. J., R. D. Vale, M. P. Sheetz, and T. S. Reese (1985) Single microtubules from squid axoplasm support bidirectional movement of organelles. Cell 40: 455-462.

Skene, J. H. P. (1984) Growth-associated proteins and the curious dichotomies of nerve regeneration. Cell 37: 697-700.

Skene, J. H. P., and M. Willard (1981a) Changes in axonally transported proteins during regeneration in toad retinal ganglion cells. $J$. Cell Biol. 89: 86-95.

Skene, J. H. P., and M. Willard (1981b) Axonally transported proteins associated with growth in rabbit central and peripheral nervous systems. J. Cell Biol. 89: 96-103.

Skene, J. H. P., and M. Willard (1981c) Electrophoretic analysis of 
axonally transported proteins in toad retinal ganglion cells. J. Neurochem. 37: 79-87.

Skene, J. H. P., and M. Willard (1981d) Characteristics of growthassociated polypeptides in regenerating toad retinal ganglion cell axons. J. Neurosci. 1: 419-426.

Sparrow, J. R., C. M. McGuinness, and B. Grafstein (1985) Goldfish optic nerve regeneration with impaired axonal transport. Anat. Rec. 211: 182A

Specht, S. C., and B. Grafstein (1976) Axonal transport and transneuronal transfer in mouse visual system following injection of ${ }^{3} \mathrm{H}-$ fucose into the eye. Exp. Neurol. 54: 352-368.

Stone, G. C., and R. Hammerschlag (1983) Glycosylation as a criterion for defining subpopulations of fast-transported proteins. J. Neurochem. 40: 1124-1133.

Stone, G. C., D. L. Wilson, and M. E. Hall (1978) Two-dimensional gel electrophoresis of proteins in rapid axoplasmic transport. Brain Res. 144: 287-302.

Stone, G. C., R. Hammerschlag, and J. Bobinski (1983) Fast-transported glycoproteins and nonglycosylated proteins contain sulfate. J. Neurochem. 41: 1085-1089.

Stromska, D. P., Z. Iqbal, and S. Ochs (1983) Evidence for the fast transport of tubulin and actin in mammalian sciatic nerve. Soc. Neurosci. Abstr. 9: 1191.

Stuermer, C. A. O., and S. S. Easter, Jr. (1984) A comparison of norma and regenerated retinotectal pathways of goldfish. J. Comp. Neurol. 223: 57-76.

Szaro, B. G., L. A. Faulkner, R. K. Hunt, and Y. P. Loh (1984) Axonal transport of $\left[{ }^{35} \mathrm{~S}\right]$ methionine labeled proteins in Xenopus optic nerve: Phases of transport and the effects of nerve crush on protein patterns. Brain Res. 297: 337-355.
Szaro, B. G., Y. P. Loh, and R. K. Hunt (1985) Specific changes in axonally transported proteins during regeneration of the frog (Xenopus laevis) optic nerve. J. Neurosci. 5: 192-208.

Whitnall, M. H. (1980) Synthesis of proteins and axonal transport of glycoproteins in normal and regenerating goldfish retinal ganglion cells. Ph.D. thesis, Cornell University Graduate School of Medical Sciences, New York.

Whitnall, M. H., and B. Grafstein (1981) The relationship between extracellular amino acids and protein synthesis is altered during axonal regeneration. Brain Res. 220: 362-366.

Whitnall, M., and B. Grafstein (1982) Perikaryal routing of newly synthesized proteins in regenerating neurons: Quantitative electron microscopic autoradiography. Brain Res. 239: 41-56.

Whitnall, M. H., and B. Grafstein (1983) Changes in perikaryal organelles during axonal regeneration in goldfish retinal ganglion cells: An analysis of protein synthesis and routing. Brain Res. 272: 49-56.

Whitnall, M., J. R. Currie, and B. Grafstein (1982) Bidirectional axonal transport of glycoproteins in goldfish optic nerve. Exp. Neurol. 75: 191-207.

Willard, M., and J. H. P. Skene (1982) Molecular events in axonal regeneration. In Repair and Regeneration of the Nervous System. Dahlem Konferenzen 1982, J. G. Nicholls, ed., pp. 71-89, SpringerVerlag, Berlin, Heidelberg, New York.

Zisapel, N., H. Levi, and I. Gozes (1980) Tubulin: An integral protein of mammalian synaptic vesicle membranes. J. Neurochem. 34: 2632.

Zwiers, H., H. Schotman, and W. Gispen (1980) Purification and some characteristics of an ACTH-sensitive protein kinase and its substrate protein in rat brain membranes. J. Neurochem. 34: 1689-1699. 